\title{
Entomological Status Based on Vector Density Index and Transovarial Infection on Aedes Sp. Mosquito in Meteseh Village, Semarang City
}

\author{
Martini Martini ${ }^{1 *}$, Zufri Armen ${ }^{1}$, Kusariana Nissa $^{1}$, Hestiningsih Retno ${ }^{1}$, Yuliawati Sri $^{1}$, \\ Mawarni Atik ${ }^{2}$, Purwantisari Susiana ${ }^{3}$ \\ ${ }^{I}$ Epidemiologi and Tropical Disease, Faculty of Public Health, Diponegoro University, Indonesia \\ ${ }^{2}$ Biostatisctics Department, Faculty of Public Health, Diponegoro University, Indonesia \\ ${ }^{3}$ Biology Department, Faculty of Science and Mathematic, Diponegoro University, Indonesia
}

\begin{abstract}
Dengue Hemorrhagic Fever (DHF) is a disease caused by Dengue virus. In 2016, the number of DHF patients in areas of Health services of Rowosari was 247 cases, IR 289.6/100.000 populations and the highest number of the patients was from Meteseh Village. The most usual mechanism happened in the vertical transmission, transovarial infection, from adult mosquito to the egg. The study was conducted to describe of entomological status of House Index (HI), Container Index (CI), Breteau Index (BI), House index (HI), Ovitrap Index (OI) of larvae as well as transovarial infection in Aedes sp. The research method was descriptive method by conducting test to the entomology status of DHF incidence. Based on the survey in Meteseh sub-village (XVI), a result found that average House Index $8.99 \%$, Container Index $2.88 \%$, Breteau Index $16.40 \%$, HI 8,99 Ovitrap Index $35.46 \%$ with the egg density at 1.023 eggs. The identified mosquitoes were 30, and from the identification result of Aedes sp., two Aedes species were found, 28 Aedes aegypti,and only 2 Aedes albopictus. The transovarial infection in Aedes sp. using ELISA method was found 6 mosquito samples which were positive of dengue virus, with the detail in neighborhood 01 (1 sample), neighborhood 02 (2 samples), neighborhood 03 (3 samples). DHF in Meteseh Sub village in Semarang City was probably happened because correlated with transovarial infection.
\end{abstract}

Keywords. Entomology Status, Aedes sp., DHF, Transovarial infection

\section{INTRODUCTION}

DHF disease, a critical virus infection disease caused by Dengue virus, infect humans of all ages but especially children with characteristics of sudden high fever by manifesting bleeding and tend to causing shock syndrome and fatal. This disease spread through the bite of either Aedes aegypti or Aedes albopictus mosquitos. The epidemic generally appears once in $4-5$

\footnotetext{
* Corresponding author: tinihen65@yahoo.co.id
} 
years and the incubation period is estimated to be approximately 7 days. The environments with many containers that may cause the water to puddle are the ideal place for the disease $[1]$.

The transmission of Dengue virus in vector mosquito could also happen vertically. This vertical transmission did not need any contact between the vector mosquito and the viremia patient. In vertical transmission, the typical mechanism occurs when the virus entering the mosquito body it infects the mosquito's ovarium and then infects the produced eggs [2]. Mosquitoes hatched from the infected eggs contained the same virus as the mother had. This vertical transmission mechanism causes the existence of Dengue virus keeps raising in the environment [4]. Unstable climate and heavy rainfall in the rainy season, the potential medium for Aedes aegypti mosquito to breed, affected the growing number of the DHF disease. Besides, the EBP activities that is not maximum in society causes Extra Ordinary Event of DHF disease takes place in some regencies/cities [3].

In Central Java Province, DHF disease is a serious problem as it has infected 35 regencies/cities. In 2015, the Incidence Rate (IR) of DHF was 47.9 per 100,000 populations; it was increasing compared with that of in 2014 that was 36.2 per 100,000 populations. The IR of DHF in Central Java Province is lower than that of the national target $(<51 / 100,000$ populations), but higher than that of the RPJMD target $(<20 / 100,000)$. In 2016, there was a decrease of incidence than that of in 2015, which was 25.22 per 100,000 populations [6].

Semarang City, a capital city of Central Java Province, is a DHF endemic city. In the first semester of 2016, the DHF patients in Semarang City were high and this problem was started to be solved in the second semester. Comparing with 2015, there was a drastically decreasing of patients from 1,737 to 448 in 2016. In case of mortality, there was a slightly increase cases from 21 in 2015 to 23 in 2016. The peak of the DHF case in 2015 and 2016 occurred in March, within the period of January to June, with 63 patients. In addition, six from big 10 IR of DHF in village level was in Tembalang sub district ${ }^{4}$. Community Health Center (Puskesmas), where its administrative area is including the entire area of Tembalang Sub district, becomes one of the Community Health Center responsible for providing extra attention to the DHF disease incidences. The number of DHF patients in 2016 was approximately 331 cases $^{5}$. Therefore, the aim of this research was to identify the general description of entomological state status based on House Index (HI), Container Index (CI), Breteau Index (BI), as well as Ovitrap Index (OI) and detect the transovarial infection in Aedes sp. mosquito in Meteseh Village, Tembalang sub district Semarang City.

\section{METHODOLOGY}

\subsection{Study Design and Sampling Procedure}

This research was conducted in RW 16 as these sub villages had the highest DHF cases in Mateseh village. This descriptive research was conducted using cross sectional approach and the population was houses in RW 16 Meteseh Village. The samples were houses in the sub village (RW) 16 Meteseh within 8 neighborhood (RT). The total houses in neighborhood 16 were 276 . Samples were selected proportionally according to the total of houses in every sub sub-villages (RT). The samples were obtained using the following formula [6].

$$
\mathrm{n}=\frac{N}{N d^{2}+1}=\frac{276}{276\left(0,05^{2}\right)+1}=163,31 \approx 170 \text { houses }
$$

Note: $n=$ sample, $N=$ Total houses, $d=$ Error tolerance (5\%) 


\subsection{Instrument Development and Data Collection Procedure}

The instrument used in this research was larva survey instruments; flashlight, pipette, and jar to store the larva found. In addition, ovitraps was also conducted by setting them in every resident house chosen as the samples, both indoor and outdoor. The ovitrap used in this research was modification ovitrap made from plastic bottle with hay infusion as an attractant [7]. The data were collected based on the larva survey result and the ovitrap setting from 276 resident houses in Meteseh village.

\subsection{Ethical Considerations}

This study used mosquito collected from the field, not using human as the subject, and we got permission from the owner through consent form before conducting the survey

\subsection{Data Processing and Analysis}

The field data collected based on the larva survey and the ovitrap setting were colonized to identify Aedes sp. mosquito. Next, by using ELISA method to identify the transovarial infection of dengue virus on Aedes sp. mosquito, the result was analyzed entomologically including House Index (HI), Container IndexI (CI), Breteau Index (BI), Larva Free Number (LFN), and Ovitrap Index (OI). The data were analyzed descriptively together with tables and maps.

\section{RESULTS}

The Village of Meteseh, Semarang City, was a DHF endemic village with 138 cases in 2014, and in 2016, 331 people were identified to be exposed. In 2017, in the period of January March, 56 people were reported to be exposed among which five cases were the resident of sub village (RW) 16[7].

The larva survey was conducted in RW 16 and the total houses to be investigated were 170 scattered around eight neighborhood (RT). Based on the indicator of entomology, the larva density in Meteseh Village was high, with the value of $\mathrm{HI}=8.99 \%, \mathrm{CI}=2.88 \%, \mathrm{BI}=16.40$ per 100 houses and $\mathrm{OI}=35.46 \%$. A high larva density was found in the area of RT 01 .

Table 1. Indicator of Entomology in Meteseh Village Tembalang, Semarang City in 2017

\begin{tabular}{cccc}
\hline Identify Status & Total Samples & Positive Larvae & \% \\
\hline House Index (HI) & 170 & 17 & 8.99 \\
Container Index (CI) & 953 & 30 & 2.88 \\
Breteau Index (BI) & 170 & 30 & 16.4 \\
Ovitrap Index (OI) & 324 & 118 & 35.46 \\
\hline
\end{tabular}

The total number of containers investigated in sub village 16 was 953 . The highest number of containers investigated was in neighborhood 03 (194 containers) and the fewest one was in neighborhood 06 (48 containers). The containers investigated positively contained 
larva was spread in five neighborhoods, while in the other three neighborhoods, no container found to be positive with larva. Among 17 houses in eight neighborhoods investigated, the highest number of containers confirmed to be positive with larva was in neighborhood 01 (11 containers), while the fewest containers or the larva infestation was not found was in several neighborhoods, neighborhood 05, 06, and 08. Meanwhile, the highest number of CI was $8.94 \%$ in neighborhood 01 , whereas the lowest number of CI with 0 percentage was in three neighborhoods, neighborhood 05, 06, and 08. The highest BI number was 45.83 in neighborhood 01 and the lowest one was 0 in neighborhood 05,06 , and 08 .

The ovitrap set in this research concerned with the mosquito population measurement especially the female mosquito to breed. The number of ovitrap set in all neighborhoods was 340, distributing in 170 houses; one ovitrap was placed indoor and the other one was set outdoor. The total number of positive ovitrap reflected the value of ovitrap index and the density of Aedes sp. mosquito eggs from each location. In this case, the highest Ovitrap Index was in neighborhood 05 at $47.73 \%$ and the lowest one was in neighborhood 4 at $20.59 \%$. Meanwhile, the highest index of egg density was in neighborhood 03 at 16.45 and the lowest one was in neighborhood 04 at 5.47 .

\subsection{Identification of Aedes sp. Mosquito}

The eggs collected from the ovitrap were colonized. The total eggs collected from all locations were 3,549 eggs, all of which were submerged to hatch the eggs. After the eggs completed the full life cycle (egg-larva-pupa-adult mosquito), investigation/identification was conducted to identify their species and gender. The result revealed that two Aedes species were identified; Aedes aegypti and Aedes albopictus.

Table 2. The Identification Result of Aedes sp. Mosquito in RW 16 Meteseh Village, Tembalang Sub district Semarang City in 2017

\begin{tabular}{ccccccccc}
\hline & Total of & \multicolumn{6}{c}{ Identification Result } \\
\cline { 3 - 8 } Neighborhood & $\begin{array}{c}\text { Investigated } \\
\text { Mosquitoes }\end{array}$ & Male & Female & \% & Male & Female & \% \\
\cline { 3 - 8 } & 4 & 3 & 0 & 75 & 0 & 1 & 25 \\
1 & 4 & 2 & 2 & 100 & 0 & 0 & 0 \\
2 & 6 & 1 & 4 & 83,33 & 0 & 1 & 16,67 \\
3 & 2 & 1 & 1 & 100 & 0 & 0 & 0 \\
4 & 4 & 1 & 3 & 100 & 0 & 0 & 0 \\
5 & 2 & 1 & 1 & 100 & 0 & 0 & 0 \\
6 & 4 & 1 & 3 & 100 & 0 & 0 & 0 \\
7 & 4 & 1 & 3 & 100 & 0 & 0 & 0 \\
8 & $\mathbf{3 0}$ & $\mathbf{1 1}$ & $\mathbf{1 7}$ & $\mathbf{9 3 , 3 3}$ & $\mathbf{0}$ & $\mathbf{2}$ & $\mathbf{6 , 6 7}$ \\
\hline Total & & & & & & &
\end{tabular}

\subsection{Transovarial Infection on Aedes sp. Mosquito}

This research found dengue virus transovarial infection on Aedes sp. mosquitoes in RW 16 Meteseh Village. The Transovarial Transmission Index (TTI) was used to measure the amount of infection rate occurrence.

Table 3 exhibits the result of Transovarial Investigation on Aedes sp. mosquitoes in RW 16 Meteseh Village, Tembalang sub district Semarang City in 2017. From 15 samples each of which consists of \pm 40 mosquitoes, the result of transovarial investigation using ELISA method showed that six samples of mosquitoes positively carried dengue virus. The samples were from neighborhood 01 ( 1 sample), neighborhood 02 (2 samples), and neighborhood 03 (3 samples). Meanwhile, the TTI in RW 16 Meteseh Village was 40\%. Given this situation, 
the DHF cases took place in the neighborhoods were positively transovarial infected by the Aedes sp. mosquitoes.

Table 3. The Result of Transovarial Investigation of Aedes $s p$. Mosquitoes in RW 16 Meteseh Village, Tembalang Sub district Semarang City in 2017

\begin{tabular}{ccccccc}
\hline $\begin{array}{c}\text { Neig } \\
\text { hbor } \\
\text { hood }\end{array}$ & $\begin{array}{c}\text { Total } \\
\text { investigate } \\
\text { d samples }\end{array}$ & \multicolumn{6}{c}{ Transovarial Investigation Result } & \multirow{2}{*}{$\begin{array}{c}\text { Total } \\
\text { DHF } \\
\text { cases }\end{array}$} \\
\cline { 3 - 6 } & 2 & 1 & 50 & 1 & 50 & 0 \\
\hline 1 & 2 & 2 & 100 & 0 & 0 & 3 \\
2 & 3 & 3 & 100 & 0 & 0 & 1 \\
3 & 1 & 0 & 0 & 1 & 100 & 0 \\
4 & 2 & 0 & 0 & 2 & 100 & 0 \\
5 & 1 & 0 & 0 & 1 & 100 & 0 \\
6 & 2 & 0 & 0 & 2 & 100 & 0 \\
7 & 2 & 0 & 0 & 2 & 100 & 1 \\
8 & $\mathbf{1 5}$ & $\mathbf{6 ( 4 0 \% )}$ & $\mathbf{3 1 , 2 5}$ & $\mathbf{9 ( 6 0 \% )}$ & $\mathbf{6 8 , 7 5}$ & $\mathbf{5}$ \\
\hline Total & 2 & & & & & \\
\hline
\end{tabular}

\section{DISCUSSION}

\subsection{Entomological status of DHF vector based on House Index (HI), Larva Free Number (LFN), Container Index (CI), Breteau Index (BI), and Ovitrap Indeks (OI)}

The percentage of $\mathrm{HI}$ explained the spread of mosquitoes in an area. The area was considered high risk to the spread of DHF disease, if the $\mathrm{HI}>5 \%$, while low risk if $\mathrm{HI}<1 \%$. The average value of $\mathrm{HI}$ in RW 16 Meteseh Village was $8.99 \%$. By referring to the standard set by WHO, the HI in RW 16 Meteseh Village fell into high risk category, which was $>5 \%$ and by following the WHO parameter, the Density Figure was on scale of 3[8].

In determining the status of DHF free in an area, LFN indicator is still in use. The LFN will be considered good if the value is $>95 \%$ from the total houses being investigated. LFN is the combination of HI, CI, and BI, by which the index of each can be calculated based on the houses, containers, and both. The average value of LFN in RW 16 Meteseh Village was $91.01 \%$, indicating that the larva density remained high [9].

The percentage of CI informs the number of total water containers positively containing larva. However, from the epidemiology perspective, the CI was lack of benefits, because it only showed the percentage of water containers positively containing larva (Aedes $s p$. breeding places). The average value of the CI in RW 16 Meteseh Village was $2.88 \%$. By referring to DHF number of WHO standard, the CI was on the scale 2, meaning that the number of containers containing positive larva to be use as the breeding places of Aedes sp. larva of DHF vector was only small [10].

From all containers fill with water in RW 16 Meteseh Village, the total containers positively containing lava was 30 with the average BI value was $16.40 \%$. If the value of the $\mathrm{BI}<50$, the area has a low risk of virus transmission occurrence, otherwise, if the value of the $\mathrm{BI}>50$, the area has a high risk of virus transmission occurrence. Besides showing the index of house containers positive larva, the BI can also be used to account the density of mosquitoes, by informing several types of container potentially to be the mosquitoes breeding place [11]. 
One of the efforts to cut off the life cycle of mosquitos could be done by setting up ovitrap, or egg and mosquito larva traps, especially targeting for Aedes aegypti. The ovitrap, commonly used in Singapore and Malaysia, known as Mosquito Larvae Trapping Device (MLTD) and has been in mass production, is an egg trap (ovum=egg, and trap) proven to suppress the growth of mosquito up to $50 \%$. Ovitrap could also be used to detect the existence of Aedes Aegypti and Aedes Albopictus when their population density was low and to do survey of non-productive larva. Ovitrap can be used to evaluate the success rate of vector restraint and to estimate the density of mosquito population [12].

The instalment of the ovitrap or egg trap could also be functioned to identify egg density of mosquitoes, measured by ovitrap index (OI), by conducting within time interval of five to six days in one instalment. The result of the research showed that the OI average value was $35.46 \%$ [13]. This value fell into level 3 category (the OI value is $20 \%-40 \%$ ).

The controlling action taken for level 3 category was the use of larvacide and insecticide for mature mosquito. The OI parameter was more sensitive compared to the BI in detecting the vector existence. In general, ovitrap was a simple and easy monitoring method because the number of eggs deposited in the standard trap within a certain time described a relative measurement of the number of mosquitoes in the same area. Therefore, it was suggested that the attachment of ovitrap in the research location could produce an effective monitoring to the vector existence in the condition of low BI value. Ovitrap do not provide an estimation of Aedes sp. population density, but it could give information of relative change in the female mosquito population [14].

By identifying the number of positive ovitrap, the value of ovitrap index and the egg density of Aedes sp. mosquito from each location could be calculated. The highest Ovitrap Index was in the neighborhood 5 at $47.73 \%$ and the lowest was in the neighborhood 4 with $20.59 \%$. The highest egg density index was in the neighborhood 3 for $1,645.16 \%$ and the lowest was in the neighborhood 4 with $547.06 \%$.

\subsection{Identification of Aedes sp. Mosquito}

The number of mosquitos of two Aedes species identified showed that Aedes aegypti was mostly found than the Aedes albopictus. This condition was influenced by the ovitrap previously installed, as 16 ovitraps all installed outdoor were gone, thus only 324 out of 340 were observed.

The existence Aedes aegypti and Aedes albopictus as the DHF vectors could be controlled by decreasing or suppressing the vector population as low as possible so their existence no longer significant to be the disease infector; however, the contact between vector and human had to be avoided. The vector disease control could be done naturally or artificially. The natural control included the control that related to geographical factors, season and climate change, wind, predator, and pest; while, the artificial one included mechanical, chemical, physical, biological, and genetical control. The control often used is fogging, which is fumigation to the imago [15].

\subsection{Transovarial Infection in Aedes sp. Mosquito}

The research result showed that there was transovarial infection in Aedes sp. mosquito, which was proven that an infection of dengue virus took place vertically from the mother to the mosquito egg.

There are three ways of transovarial arbovirus infection in mosquito: (1) Uninfected female mosquito suck the blood of viremic host, the virus replicates in mosquito and infect the egg, which later produces infected larva; (2) Uninfected female mosquito mates with the transovarially infected male mosquito. During the mating process, a sexual infection occurs 
affecting the ovarium of female mosquito to be infected by the virus; (3) Female mosquito gets a virus infection in its ovarium tissue that stays until the next generation genetically [16].

The number of transovarial infection in RW 16 Meteseh Village was 40\%. The colonized eggs from eight neighborhoods were 15 groups; six of which were positive containing dengue virus spread in the neighborhood 1, the neighborhood 2, and the neighborhood 3.

The research by Hartanti D M in Tebet, South Jakarta, which was the highest of DHF prevalence in Indonesia, concluded that there is transovarial transmission of dengue virus in the local DHF vector. However, there is no significant difference between the area with the highest and the lowest DHF prevalence in 2009 in Kecamatan Tebet [17].

\section{CONCLUSION}

The entomological status based on the House Index, Larva Free Number, Container Index, Breteau Index, Ovitrap Index is considered in the high category. The identified mosquitoes are 30, two species are identified, Aedes aegypti around 93.33\% and Aedes albopictus only $6.67 \%$. The Transovarial infection in the Aedes sp. mosquito from the transovarial investigation result using ELISA method was obtained 6 samples of mosquitoes with positive dengue virus.

\section{Acknowledgement}

We thank to staff Research and Development Unit for Zoonosis Control, Banjarnegara, for data identifying.

\section{REFERENCES}

1. AMH. Sorisi, Transmisi Transovarial Virus Dengue Pada Nyamuk Aedes spp Epidemiologi, J. Biomed, 5 (1) :23, (2013)

2. FA. Siregar, Epidemiologi dan Pemberantasan Demam Berdarah Dengue (DBD) di Indonesia. FKM. USU, (2004)

3. N. Pramestuti, D. Widiastuti, J. Raharjo, Transmisi Trans-Ovari Virus Dengue Pada Nyamuk Aedes aegypti dan Aedes albopictus Di Kabupaten Banjarnegara. J. Ekolog. Kes. 12 (3) :187-94, (2013)

4. Dinas Kesehatan Kota Semarang. Profil Kesehatan Kota Semarang 2015. www.dinkes.semarangkota.go.id.go.id. diakses pada tanggal 24 Maret 2017, (2017)

5. Puskesmas Rowosari. Laporan Penderita DBD tahun 2017, (2017)

6. Martini M, A. Prihatnolo, R. Hestiningsih, Modified Ovitrap to Control Aedes sp Population in Central Java, Indonesia. J. Commun. Dis. 2017; 49 (3): 52-56, (2017)

7. N. Notoatmodjo, Metode Penelitian Kesehatan. Jakarta: Rhineka Cipta, (2010)

8. PNA. Wati, Survei Entomologi Dan Penentuan Maya Index Di Daerah Endemis DBD Di Dusun Krapyak Kulon, Desa Panggungharjo, Kecamatan Sewon, Kabupaten Bantul, DIY. J. Med. Respati, 10 (3):77, (2015)

9. M.R. Rida, N. Rahayu, N.A Rosvita, D.E. Setyaningtyas, Hubungan kondisi lingkungan dan kontainer dengan keberadaan jentik nyamuk Aedes aegypti di daerah endemis demam berdarah dengue di kota Banjarbaru. J. Buski, 4 (3):133-7, (2013)

10. Nomitasari, L.D. Saraswati, P. Ginandjar, Perbedaan praktik PSN 3M Plus di Kelurahan Percontohan Dan Non Percontohan Program Pemantauan Jentik Rutin Kota Semarang. J. Ento. Indo, 9 (1):32-7, (2012)

11. JVI. Sambuaga, Status Entomologi Vektor Demam Berdarah Dengue Di Kelurahan Perkamil Kecamatan Tikala Kota Manado Tahun 2011. J. Kes. Ling, 1 (1):54-61, (2011) 
12. N.K. Latifa, W.B. Arusyid, T. Iswidaty, D. Sutiningsih, Pengaruh Ovitrap Sebagai Monitoring Keberadaan Vektor Aedes sp di Kelurahan Bulusan Kecamatan Tembalang Kota Semarang. J. Ilm. Mhs, 3 (1):26-9, (2013)

13. A. Candra, Demam Berdarah Dengue : Epidemiologi, Patogenesis, dan Faktor Risiko Penularan. Aspirator, 2 (2):110-9. (2010)

14. Sunaryo, N. Pramestuti Surveilans Aedes aegypti di Daerah Endemis Demam Berdarah Dengue. J. Kes. Mas. Nas, 8 (8):423-9 (2014)

15. Y. Yasmin, L. Fitri. Perubahan Morfologi Larva Nyamuk Akibat Pemberian Larvasida Bakteri Kitinolitik. J. Ento. Indo,, 10 (1):18-23 (2013)

16. M.D. Hartanti, I.A. Tirtadjaja. DengueVirus Transovarial Transmission By Aedes Aegypti. Universa. Med, 29 (2):65-70 (2010) 